\title{
7 The Dutch shipbuilding industry, 1950-2012
}

\author{
Sjaakvan der Velden
}

\section{Introduction}

In 2012, shipbuilding production and repair represented only 1.3 per cent of the total industrial volume of the Netherlands.' Sixty years ago, Dutch shipbuilding and repair's share of total industrial volume was approximately 12 per cent; thus its percentage has diminished to about one-tenth of the 1952 share. In 2012, there were 75 shipbuilding companies employing 11,850 workers active in the Netherlands, as against 136 in 1952 , employing 48,333 workers. ${ }^{2}$ Hence, over the period, the number of companies has diminished markedly, and total employment in Dutch shipbuilding and repair has decreased by 75 per cent.

It is not only the numbers that have changed; the product has too. While the industry produced mainly passenger and general cargo ships in the 1950s, nowadays it focuses on specialist offshore vessels and super-yachts.

\section{Short history of Dutch shipbuilding during the Second World War and aftermath $^{3}$}

During the period before the Second World War metalworkers generally, and workers in the shipbuilding industry in particular, were among the most strikeprone of the Dutch working class. According to the data collected by Clarke Kerr and Abraham Siegel, metalworkers in the Netherlands showed an average propensity to strike; however, my own database of strikes makes it clear that in the metal industry workers were more than averagely prone to take strike action. ${ }^{4}$

The years of Nazi occupation of the Netherlands were characterised by passive resistance on the part of the workforce, which caused production to

\footnotetext{
1 Scheepsbouw Nederland, Jaarverslag 2012, 75.

2 CBS, Scheepsbouw-en scheepsbouwreparatiebedrijven 1952.

3 Dirkzwager, "Scheepsbouw".

4 Kerr and Siegel, "The Interindustry Propensity to Strike”, 209-210; van der Velden, Stakingen in Nederland, 195. The difference between the Kerr-Siegel findings and my own has much to do with the fact that the Dutch dataset of strikes and lock-outs is on a micro level, while Kerr and Siegel used data of a highly aggregated level. See also Hamark, "Strikingly Indifferent".
} 
Figure 7.1 Production, Dutch shipbuilding industry, 1951-1986 (1951=100; in mn 1951 guilders)

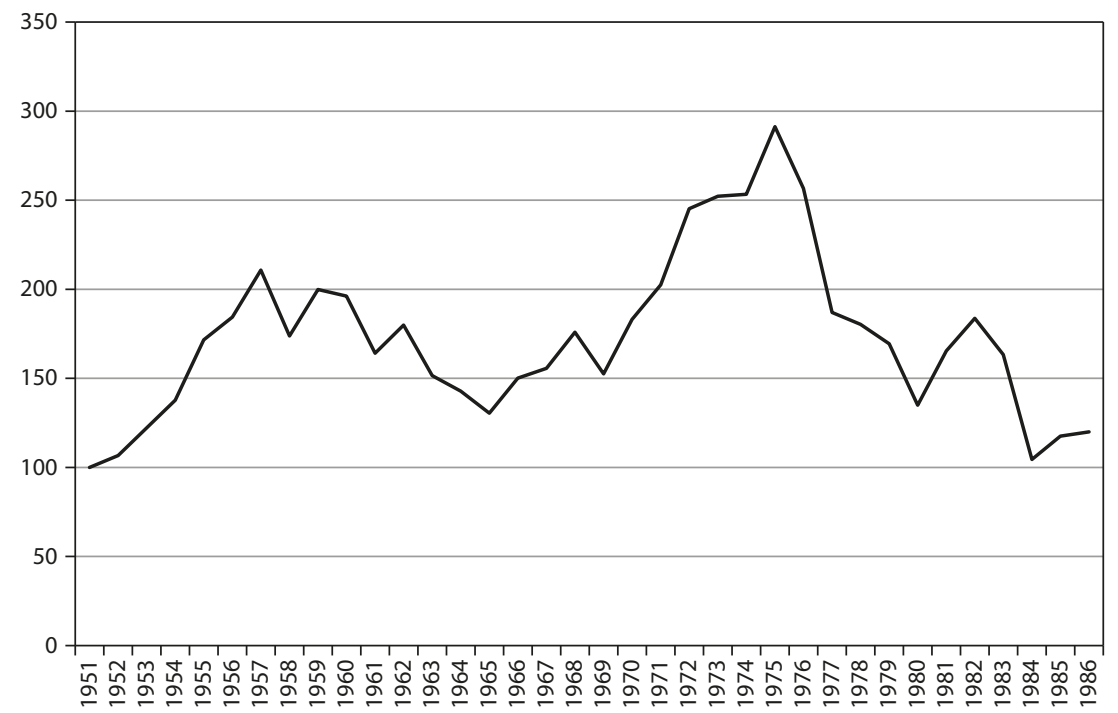

Source: CBS, Produktiestatistieken Industrie. Scheepsbouw-en scheepsbouwreparatiebedrijven 1951-1986 (1959-87)

be extremely low. For example, at the Rotterdamse Droogdok Maatschappij (RDM) shipyard, twelve torpedo-boat destroyers were ordered by the Kriegsmarine of which not one was completed. ${ }^{5}$ At other shipyards work for the Germans was also sabotaged. ${ }^{6}$ When the Nazis realised that defeat was likely, they destroyed much of the infrastructure of the Amsterdam and Rotterdam ports, including parts of the shipyards. ${ }^{7}$

After the defeat of the Nazis, the Dutch government stressed the priority of reconstructing the economy. The main policy tool used was a strict policy on prices and wages in an attempt to limit inflation. This wage policy and the refusal to negotiate with radical labour unions, in tandem with shortages of food as the Netherlands readjusted to a peacetime economy and efforts to employ people who had collaborated with the Nazis, led to a wave of strikes in the immediate post-war period. ${ }^{8}$ Within a few years, however, this wave

5 Van den Aardweg et al., 1900-1952. Een halve eeuw "Droogdok", 151.

6 Van Borselen, De Kriegsmarine in Rotterdam, 203.

7 De Jong, Het Koninkrijk der Nederlanden, vol. 1ob, 7.

8 Harmsen and Reinalda, Voor de bevrijding van de arbeid, 268-270. 
Figure 7.2 Total production, Dutch shipbuilding: building and repair, 1950-1972 (in mn 1951 guilders)

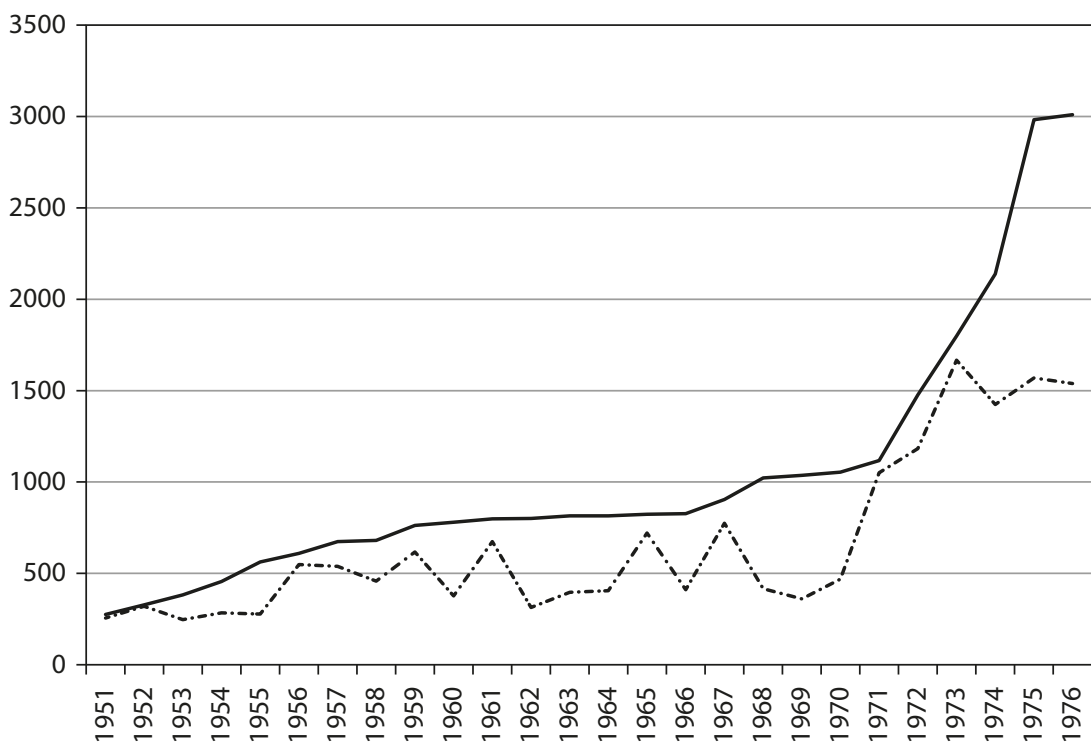

— Building -.... Repair

Source: CBS, Produktiestatistieken Industrie. Scheepsbouw- en scheepsbouwreparatiebedrijven 1951-1986 (1959-87)

ebbed as sustained economic growth made improvement of working-class life possible. The post-war strike wave was, however, also strongly opposed by officials and politicians who feared a repetition of the labour unrest that had followed the First World War. They did everything in their power to stop the activities of the EVC (Eenheids Vakcentrale, Unity Union) and striking workers. ${ }^{9}$

By around 1950, Dutch shipbuilding had recovered from the consequences of the war. This recovery was largely the result of ship repairing activities, which were more cost-effective than new construction. Things were, however, to change irreversibly. Because of the Japanese occupation during the war, the Dutch had lost control over the former Dutch East Indies, now Indonesia. Two days after the surrender of Japan in August 1945, led by the nationalist leader Sukarno, Indonesia declared independence, and Sukarno was appointed president. The Dutch attempted to re-establish colonial hegemony, and the 
resulting conflict ended in December 1949, when, facing increasing international pressure, the Dutch finally recognised Indonesian independence. ${ }^{10}$

This was a serious setback for Dutch liner shipping companies which had previously relied on trading to and from Indonesia. As a consequence the Dutch shipyards that repaired and built ships for these shipping companies feared that their sales would also plummet. ${ }^{11}$ However, despite this threat, the shipbuilding industry developed positively, as Figure 7.1 shows, in terms of production of ships from 1951 onwards. By 1957, production of ships had doubled; it dropped from 1960 to 1965 , and rose again to a peak in 1975-1976, before declining in the extended wake of the OPEC quadrupling of oil prices and subsequent recession in world trade, so much so that, by 1986, the total value of Dutch shipbuilding and repair had almost returned to the level of 1951.

Figure 7.2 makes it clear that in most years the value of the building of new ships and of repair were roughly the same size until the early 1970s. Then building became much bigger than repair as a part of total production.

\section{Location and importance of shipyards}

In 1889 only three big shipyards existed (in Amsterdam, Rotterdam, and Vlissingen) but this number expanded when a few new companies were established, mainly in the Rotterdam area. ${ }^{12}$ During the twentieth century, the Dutch shipbuilding industry was concentrated near the port of Rotterdam, with minor concentrations in Amsterdam and Vlissingen and in the province of Groningen. In Groningen the yards built many smaller inland vessels while the shipyard in Vlissingen (De Schelde) mainly built warships for the Royal Dutch Navy. In the Amsterdam and Rotterdam areas the shipyards largely built passenger and general cargo ships.

The seven largest shipbuilding companies in the Netherlands were labelled the "seven sisters" by a parliamentary research commission that investigated the problems of the Dutch shipbuilding industry in 1984-1985. In doing so they acknowledged the importance of these seven companies which had a similar impact on Dutch shipbuilding as had the "seven sisters" on the international oil trade..$^{13}$

Woltjer, Recent verleden, 179-207.

Van Zanden and Griffiths, Economische geschiedenis van Nederland, 8o.

Brugmans, Paardenkracht en mensenmacht, 319.

Sampson, The Seven Sisters. 
THE DUTCH SHIPBUILDING INDUSTRY, 1950-2012
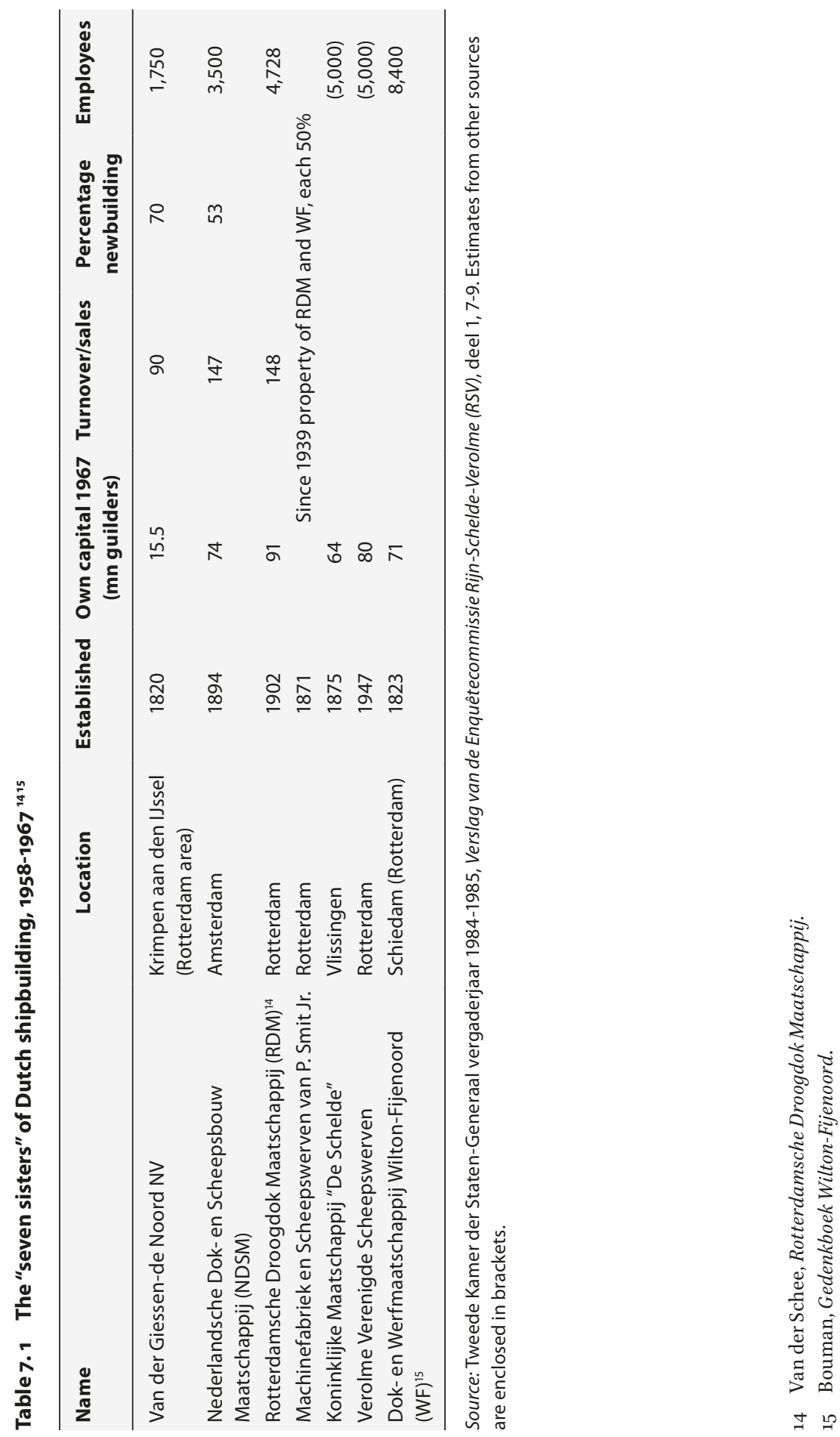
Table 7.2 Shipbuilding companies with more than fifty employees compared to the seven sisters, 1958-1967

\begin{tabular}{lccccccc}
\hline Year & $\begin{array}{c}\text { Number } \\
\text { of } \\
\text { companies }\end{array}$ & $\begin{array}{c}\text { Sales } \\
\text { in } \mathbf{~ m n}\end{array}$ & $\begin{array}{c}\text { Wuilders } \\
\text { gurkers }\end{array}$ & $\begin{array}{c}\text { Sales by } \\
\text { seven } \\
\text { sisters }\end{array}$ & $\begin{array}{c}\text { Percent- } \\
\text { age of } \\
\text { total sales }\end{array}$ & $\begin{array}{c}\text { Employment } \\
\text { with seven } \\
\text { sisters }\end{array}$ & $\begin{array}{c}\text { Percentage } \\
\text { of total } \\
\text { employment }\end{array}$ \\
\hline 1958 & 107 & 1,315 & 53,836 & 985.7 & 75.0 & 29,122 & 54.1 \\
1959 & 101 & 1,512 & 51,608 & & & & \\
1960 & 100 & 1,608 & 49,975 & 819.9 & 51.0 & 27,199 & 54.4 \\
1961 & 100 & 1,345 & 49,180 & & & & \\
1962 & 98 & 1,531 & 49,091 & & & & \\
1963 & 94 & 1,290 & 46,252 & 674 & 52.2 & & \\
1964 & 94 & 1,306 & 44,634 & & & & \\
1965 & 91 & 1,275 & 43,545 & 777.2 & 61.0 & 24,153 & 55.5 \\
1966 & 91 & 1,515 & 42,600 & & & & \\
1967 & 88 & 1,668 & 42,821 & 921.8 & 55.3 & 23,355 & 54.5 \\
\hline
\end{tabular}

Source: CBS, Produktiestatistieken Industrie. Scheepsbouw- en scheepsbouwreparatiebedrijven 1958-1967 (1959-68); Tweede Kamer der Staten-Generaal vergaderjaar 1984-1985, Verslag van de Enquêtecommissie Rijn-Schelde-Verolme (RSV), deel 1, 6-9. Unfortunately figures from this source are incomplete and therefore do not allow the construction of an uninterrupted series.

These seven biggest companies, out of a total of around one hundred companies, accounted for a disproportionate amount of sales and employment as can be seen from Table 7.2.

From Figure 7.1, it is clear that shipbuilding production rose steadily to the end of the 1950 s and peaked in the mid-1970s. From then it declined, as did the numbers of employees and value of sales. ${ }^{16}$ There were on average a little under one hundred companies with more than fifty employees during those years, but the seven sisters accounted for almost 59 per cent of annual sales in $195^{8-1967.17}$

\section{The $1950 \mathrm{~s}$}

During the 1950s there was still a sense of euphoria in Dutch shipbuilding. Big passenger liners were built - such as the 35,000-ton SS Rotterdam, built by RDM in 1959 - and a new company was established, Verolme Verenigde Scheepswerven (Verolme United Shipyards). The latter was the work of one

16 CBS, Produktiestatistieken Industrie. Scheepsbouw-en scheepsbouwreparatiebedrijven 1951$1986(1959-87)$.

17 I calculated the average of the given shares in Table 7.2 . 
man, Cornelis Verolme, who stood outside the existing Rotterdam metal industry elite. ${ }^{18}$ Verolme refused to co-operate closely with the other companies in the Rotterdam area that were united in the employers' organisation, the Metaalbond (Metal Union), which had taken a firm stand against labour unions since the beginning of the twentieth century. Verolme was able to obtain huge profits in comparison to the other "sisters". During the years 1957-1967 Verolme had a net profit that was much higher than the others combined. He earned $167.9 \mathrm{mn}$ guilders, while the others made $101.5 \mathrm{mn} .^{19}$ As he was the sole owner (no other shareholders were involved), Verolme's company was, despite the good results, vulnerable. It was not easy for him to attract outside capital to expand and renew the company.

\section{Growth and decline}

In general the 1960 s was a period of economic growth in the Netherlands. The welfare state also grew, and workers managed to obtain higher wages by way of a series of wildcat strikes. Through these strikes workers tackled the system of wage control that had existed since 1945. When the state abandoned such control in 1963, wages started rising rapidly, including in the shipbuilding industry(Figure 7.3). In general, wages in the metalworking industry were lower than the average for the entire Dutch industry. For example, in 1966 metalworking wages per hour were 375 cents while the overall average was 384 cents. $^{20}$ But nominal wages rose year after year until the mid-1970s. ${ }^{21}$

During the 196os, labour became expensive in relation to the 1950s, when wages in the Netherlands were among the lowest in Europe. To cut costs, companies merged, employees were sacked, and capital looked for more profitable opportunities by moving to countries where wages and labour costs in general were lower. One of the first industries where this happened was shipping. Others were clothing and shipbuilding. ${ }^{22}$ From 1967 unemployment started to rise and, with the crisis of the $1930 \mathrm{~s}$ in mind, most of those involved in the political scene became convinced that it was time to turn the tide. One of the important economic sectors that drew

\footnotetext{
18 Verolme, Memoires met medewerking van Leo Ott; Dekker, Cornelis Verolme.

19 Tweede Kamer der Staten-Generaal vergaderjaar 1984-1985, Verslagvan de Enquêtecommissie Rijn-Schelde-Verolme (RSV), deel 1, 7 .

20 CBS, Statistisch Zakboek 1972, 252.

21 CBS, Vijfennegentig jaren statistiek in tijdreeksen 1899-1994, 50.

Van Zanden en R.T. Griffiths, Economische geschiedenis van Nederland in de $20^{e}$ eeuw, 269.
} 
Figure 7.3 Wages in the Dutch shipbuilding industry, 1952-1986 (1952=100)

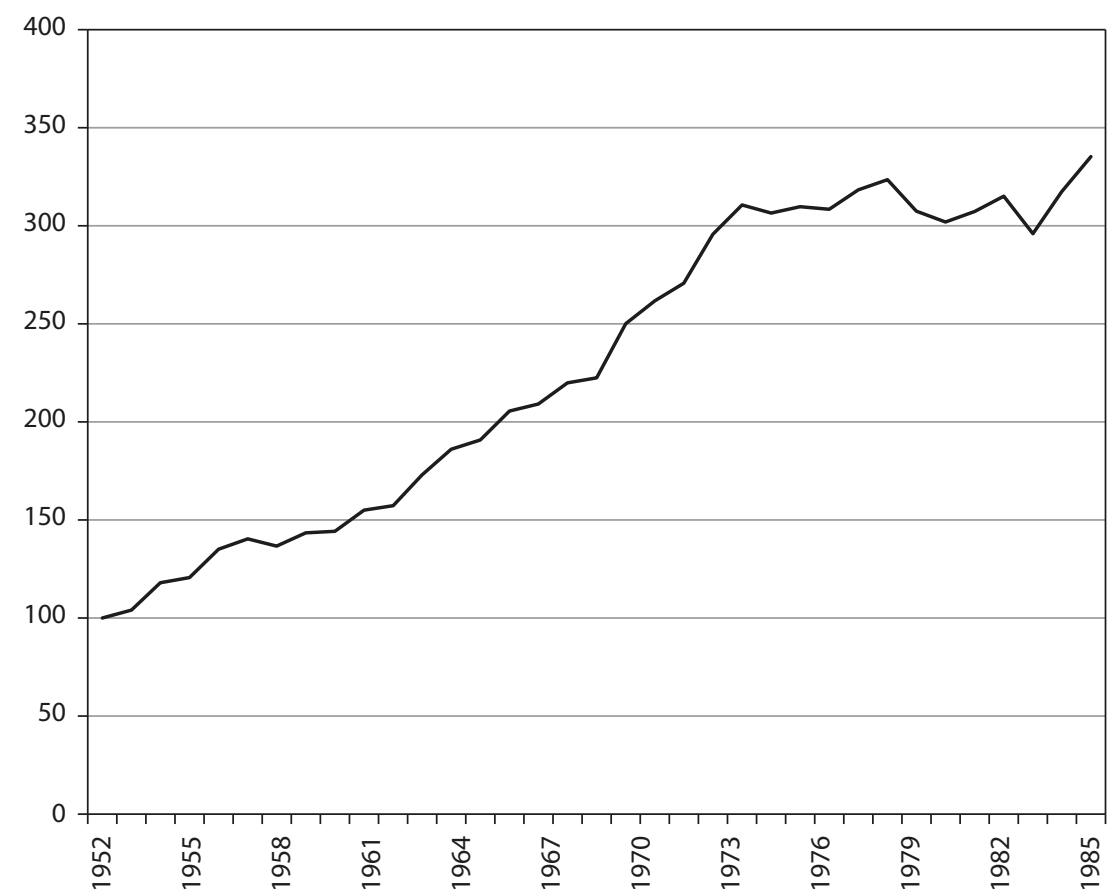

Source: CBS, Produktiestatistieken Industrie. Scheepsbouw- en scheepsbouwreparatiebedrijven 1951-1986 (1952-87)

the attention of the state was the shipbuilding industry as it had begun to exhibit signs of a slow and probable decline. In 1930, the Dutch shipbuilding industry had been the third-largest in the world (after the United Kingdom and Germany) but those days were over. From 1956 Japan, and later, Sweden outstripped the Netherlands; by the end of the 196os the Dutch occupied a lowly fourteenth place in the world shipbuilding league table. ${ }^{23}$

Pressed by parliament, the Dutch government established a research commission in 1965 to investigate the problems. This Commissie Keyzer (Keyzer Commission), named after its chairman, intended to devise a common policy for the state and the industry to follow with regard to shipbuilding. ${ }^{24}$ Contemporaneously, the European Economic Community

23 Tweede Kamer der Staten-Generaal vergaderjaar 1984-1985, Verslagvan de Enquêtecommissie Rijn-Schelde-Verolme (RSV), deel 1, 4.

24 Rapport van de Commissie Nederlandse scheepsbouw 1965. 
proposed a policy that allowed its member states to place orders with their own industry without actually giving subsidies to the companies involved. ${ }^{25}$

When the Commissie Keyzer published its findings in 1966, it came to three conclusions. Dutch shipbuilding had suffered from the fact that it received no state support in the form of subsidies, while other countries did; the industry was unable to attract young workers; and it was too conservative in its working methods. It leant too heavily on craftsmanship instead of trying to industrialise shipbuilding. ${ }^{26}$ In short, Dutch shipyards had not kept pace with advances elsewhere in production methods and were insufficiently specialised.

The recommendations of the commission implied co-operation and mergers of the seven major existing companies in order to foster specialisation in products and to modernise shipbuilding through standardised serial production. Another important recommendation was the introduction of a state subsidy to enable shipyards to match those subsidies given to shipowners elsewhere. Following the conclusions of the Commissie Keyzer, the Dutch government decided in 1967 to support the industry if companies actively engaged in innovation and a restructuring of the sector. A good example of the way this worked is the support that Verolme received in 1968. He obtained a state guarantee for the building of a new dock as a reward for taking over the unprofitable NDSM shipyard in Amsterdam. Two years earlier, a few of the seven sisters had already decided to co-operate more closely in order to be able to build larger ships. The building of tankers (66,00o tons or more) had become urgent after the closing of the Suez Canal in 1956, and this trend was strengthened as a result of the Six-Day War between Israel and Egypt in 1967.

In 1966, RDM (including its subsidiary Piet Smit) and De Schelde merged to form Rijn-Schelde Machinefabrieken en Scheepswerven NV (RSMS) or Rijn-Schelde. Other shipyards including Wilton-Fijenoord joined in 1968, but this was not the end of the merging process. Despite the state support for Verolme, the construction of supertankers at the former NDSM shipyard and at the new Verolme shipyard in Rotterdam was not profitable. Continuing losses tempted Verolme to ask for more support, which was granted only on the condition that Verolme and Rijn-Schelde merged. In January 1971, the two companies merged into Rijn-Schelde-Verolme Machinefabrieken en Scheepswerven NV (RSV). Within a few years six of the seven sisters of

25 Tweede Kamer der Staten-Generaal vergaderjaar 1984-1985, Verslagvan de Enquêtecommissie Rijn-Schelde-Verolme (RSV), deel 1, 14.

26 Rapport van de Commissie Nederlandse scheepsbouw 1965. 
Dutch shipbuilding had merged into one single company, together with a few engine-manufacturing factories. Only Van der Giessen-de Noord had stayed out of this merger (see Appendix 4).

The RSV concern was now in a stronger position regarding the Dutch state. It employed many thousands of workers, and with each restructuring the state had also stipulated that a merger should not jeopardise employment. Internally, the concern was no more than a combination of several companies that did not really work together; hence the potential advantages of economies of scale and scope of RSV were limited. The economic crisis of 1973-74 also worked in favour of RSV, not just because for a short period it stimulated the building of new supertankers, ${ }^{27}$ but also because the government was convinced that it should follow an anti-cyclical policy. The maintenance of jobs was considered very important by the governing Social Democrat Party, and RSV was therefore well supported, not only with orders for the Royal Netherlands Navy, but also with financial support. Later governments, in which there was no social democratic representation, continued this policy. In 1977 , the state even agreed that it would cover 75 per cent of the calculated company losses. ${ }^{28}$ Between 1967 and 1983 the Dutch state thus financially supported RSV with 2,700 mn guilders, which was roughly 5 per cent of total sales of the entire Dutch shipbuilding industry for the period. ${ }^{29}$

Financial support from the state was conditional on RSV restructuring several times during the second part of the 1970s. Each time employment decreased and the company became a little more stable, but it was ultimately in vain. When the company asked for new support in 1983, after having received aid in 1982, the government finally decided to cut its losses. ${ }^{30} \mathrm{RSV}$ entered bankruptcy and the remaining 5 , 00o workers of the company - of which the component parts had employed around 30,00o men during the mid-1970s - lost their jobs.

The extended demise of RSV changed the entire landscape of Dutch shipbuilding. Some parts of RSV were actually closed; other parts were saved. De Schelde became the property of the state and the province of Zeeland..$^{31}$ In Amsterdam there is no shipbuilding left apart from a few ship repair yards, and the big companies in and around Rotterdam were also closed and some parts sold to other companies. The once huge Verolme

27 In 1974, Verolme delivered the biggest ship ever built in the Netherlands: Lepton, an oil tanker of 318,00o dwt.

28 Van Zanden, Economische geschiedenis, 83 .

29 Ibid., 84.

30 Graf, Een ongelijke strijd.

31 Quite, Koninklijke Mij. "De Schelde". 
shipyard is now part of the Singapore-based specialist ship repairers, Keppel Corporation. In Vlissingen the shipyard of De Schelde still exists despite being sold by the state and the province in 2000. It is now part of the Dutch Damen Shipyards Group building for the navy while other parts of the group build yachts and inland vessels. Dutch shipbuilding nowadays is much reduced from its heyday, but what remains has specialised in niche markets and is relatively healthy.

\section{A highly unionised and strike-prone workforce}

The social democratic metalworkers' union (Algemeene Nederlandsche Metaalbewerkers Bond, ANMB) was the biggest Dutch trade union in the years between the two world wars. Union membership in the metal industry generally was also among the highest in the entire economy. Due to the lack of available data the extent of trade union membership in the Dutch shipbuilding industry is impossible to calculate. However, the overall union penetration of the Dutch metal industry in the 1930s was roughly 41 per cent, although in the Amsterdam and Rotterdam regions numbers were higher (47 and 48.8 per cent respectively)..$^{22}$ There were also a number of unions besides the ANMB that represented metalworkers. The ANMB was by far the largest, comprising almost 60 per cent of total union membership; in addition the Roman Catholic Union accounted for 22.6 per cent of total membership, the Protestant Union for 12 per cent, and two small revolutionary unions less than 3 per cent. ${ }^{33}$

The combined metal unions negotiated collective agreements with the companies which for their part wanted such agreements in order to prevent competition on the labour market. Most employers also wanted a general wage standard to prevent competitors attracting workers by offering higher wages. This scenario would end with higher wages for the whole industry - not exactly an endpoint that would please employers - hence they were prepared to sign collective agreements. ${ }^{34}$ After the German occupation this system returned within the policy of strict wage regulation initiated by the state. There was, however, a problem with a newly established radical labour union,

32 Own calculations from CBS, Overzicht van den omvang der vakbeweging in Nederland op ı januari 1932; digitised census 1930, www.volkstelling.nl/nl/volkstelling/jaartellingdeelview/ BRT193007/index.html.

33 CBS, Overzicht van den omvang der vakbeweging in Nederland op 1 januari 1932.

34 Binneveld, De stakingen in de Rotterdamse metaalindustrie in 1965, 35. 
EVC. Many workers joined this new organisation, which was clearly a result of the war resistance. EVC wanted to do away with the pre-war division within the union movement, which encouraged workers to join a union of their own "pillar" instead of joining the one union that aimed to organise the entire working class. Because of its apparent radicalism shown during a number of big strikes, especially in the port of Rotterdam, both employers and the state refused to accept EVC at the negotiation tables. It took until 1950 before the role of this union was finished, and the old relations had been restored. EVC still existed; however, most union members rejoined the pre-war unions. ${ }^{35}$

There was, however, one big change. Within the leaderships of the three major pre-war unions there was a changed state of mind. This attitude can possibly be best illustrated by citing the chairman of the Rotterdam branch of the ANMB who in 1954 wrote:

social struggle in the past could not be carried out other than by the sharpest weapon of class struggle; the strike must be regarded historically only as a social evil, as a tragic episode in the development of mankind to a higher stage. ${ }^{36}$

This comment highlighted a tendency in the official labour movement to participate in the new social and economic policy of post-war governments, stimulated by the welcoming of the unions into a number of new organs of management, the tripartite system which came into being in the years 1945-1950 and was still intact in 2014. Part of this management was regular consultation between employers' organisations, labour unions, and the state. In such consultations, collective agreements were settled for entire industries like metals or construction. The unions, which were originally organised along professional lines, were now also structured along industrial lines. ${ }^{37}$

Under this new tripartite approach, labour unions became a well-respected part of management, and they therefore almost never issued a strike call during the 1950s. However, this did not prevent workers from staging wildcat strikes during that period. This new attitude of the union movement had a

Van der Velden, Werknemers georganiseerd, 131, 180.

36 "Dat de sociale strijd in het verleden niet anders dan door het scherpste wapen van de klassenstrijd: de staking, kon worden gevoerd, moet - historisch gezien - slechts als een maatschappelijk kwaad, als een brok tragiek in de ontwikkeling van de mensheid naar een hoger plan worden gezien": Wacht, Heet voor de vuren, 242.

37 For a good overview of the early history of the Dutch tripartite system of labour relations, see Windmuller, Labor Relations in the Netherlands. 
Figure 7.4 Number of strikes in the Dutch shipbuilding industry, 1950-2013

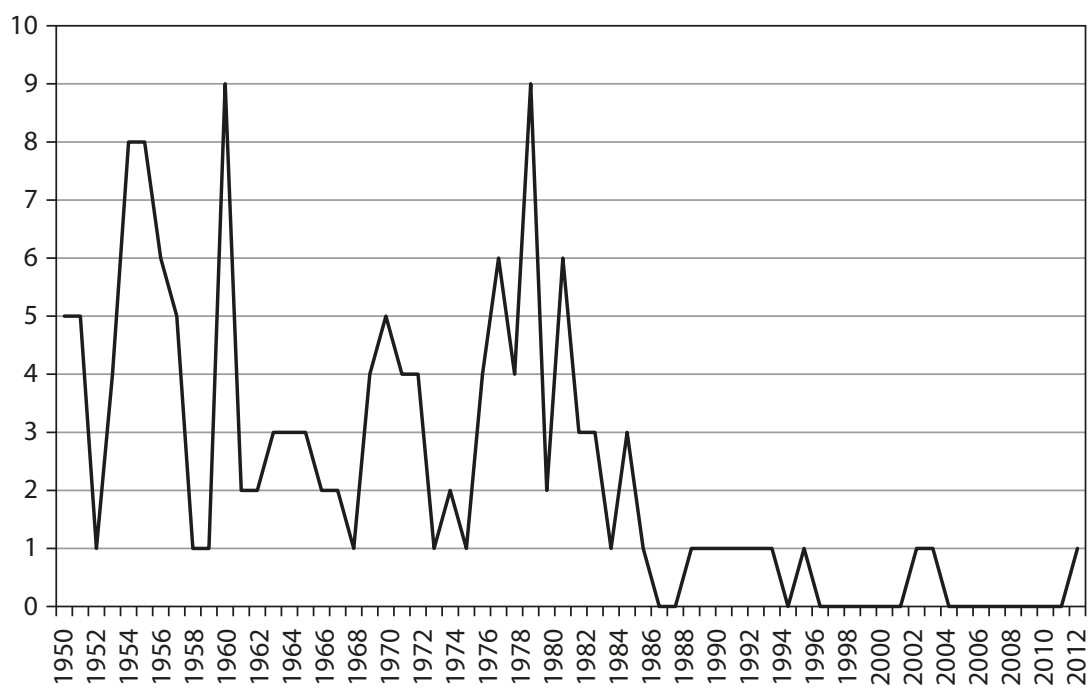

Source: http://socialhistory.org/en/stakingen; 2008-13 data are from author's own database

counterpart in what is termed the social policy of many employers. Since the 1870 s there had been developments, especially within the industry, towards affording better education and housing for the workers. This movement started in reaction to the threat of the emerging labour movement combined with the social attitude of certain individual employers. ${ }^{38}$ This combination of interests was strengthened by certain specific factors. The Rotterdam metal employers had problems with recruiting skilled labour. It was therefore in their own interest to attract workers by providing accommodation. A good example of this is the living quarters built by RDM in Rotterdam Heyplaat. ${ }^{39}$ This quarter was built in 1914 according to the principles of garden villages, like other quarters built in the Netherlands, such as the quarter De Schelde erected for its workers in Vlissingen. What the companies attempted to foster was a form of community feeling among the workforce by affording all kind of facilities including libraries, musical societies, and sports clubs. ${ }^{40}$

38 Nijhof, «Villages ouvriers: de l'idéalisme au pragmatisme?», 16.

39 Van den Aardweg et al., 1900-1952. Een halve eeuw "Droogdok", 65, 211-225.

40 Ibid., 221. Other industrialists known as social entrepreneurs were already active at the end of the nineteenth century; see Kleij, Sociaal Ondernemerschap. 
Figure 7.5 Number of strikers and number of strike-days, 1950-2008

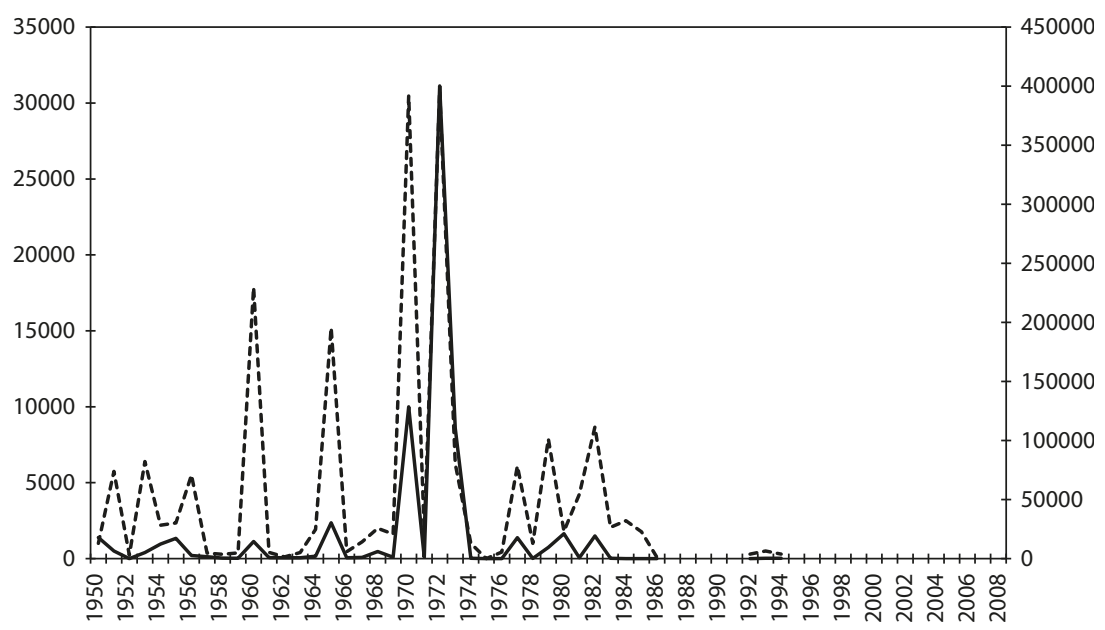

--- Strikers (left) — Strikedays (right)

Source: http://socialhistory.org/en/stakingen

Figure 7.4 illustrates the number of strikes in the shipbuilding industry from 1950 to 2013. It shows that the trend of strike frequency is diminishing. After a fairly high number of strikes during the 1950s, the 1960s saw fewer. The 1970s started with an upsurge while during the early 1980 s strike frequency returned to the level of the 1950s. This was understandable at a time when workers in shipbuilding felt a constant threat of sackings because the state wanted to stop financial support to the industry and especially RSV. To get a better picture of strike activity I present in Figure 7.5 two other strike indicators: the number of strikers and the number of strike-days.

Looking at Figures 7.4 and 7.5 together makes it clear that the 1970 and 1980 s were periods of a higher strike activity. The total numbers of strikers and days lost to strikes in the two decades to 1970 were lower but, although the number of strikes was higher, they had less impact in terms of days lost than the strikes in the early 1970s.

After the initial strike wave just after the war, the 1950s saw few and small strike events. The labour conflicts that occurred were in most cases unofficial wildcat strikes by union members because the union leaderships were primarily engaged in deliberating in the tripartite system and this, necessarily, took time, leaving local matters unresolved. Despite the grow th of the Dutch welfare state, many workers were unsatisfied by recent 
developments. In 1957, Dutch wages were among the lowest in Europe and workers naturally wanted higher wages for comparable work. From 1959, a strike wave developed in order to end the strict wage policy in order to raise wages. The metal industry, including ship building, also played a role in this movement. ${ }^{41}$ The following strike stories are taken from the website http://socialhistory.org/en/stakingen. Only literal quotes receive a footnote from the original source.

\section{Overview of strike movements}

In 1960, the 4,000 workers of the NDSM in Amsterdam struck for the payment of travel expenses and a 45-hour working week. They were not supported by the unions but nevertheless reached a settlement after two days. Travel expenses would be met in the future. This was one of the nine strikes that took place in shipbuilding in 1960 . Most were on a small scale, but from 24 November a nationwide strike by 24,000 workers from 35 companies started in the metal industry, including shipbuilding. This strike movement started without the approval of the unions, although the strikers supported the unions during their negotiations for a new collective agreement. Most shipbuilding workers participated for a short period or a number of periods. The 800 workers of the Amsterdamse Droogdok Maatschappij (ADM) for example, joined for two and a half days, and their counterparts of RDM struck for a few hours. The 5,000 workers of WiltonFijenoord (WF) resumed work after a few hours, although two days later, $55^{\circ}$ of them struck again; on 8 December, 3,00o WF workers joined the strike again. They demonstrated through the streets of Schiedam (a small city close to Rotterdam) to express their anger about the government's refusal to grant a wage rise of 3 per cent.

Strikes like this were the reason for a discussion within the union movement about the lost connection between the leadership and the rank and file. It was acknowledged by social researchers invited by the Metalworkers' Union to study this discrepancy between management and members that a union with unsatisfied members, who, at times, threatened to terminate membership, might be a threat to the credibility of the unions in the eyes of employers and the state. ${ }^{42}$ 
Five years later an event took place known as the Rotterdam metal strike of $1965 \cdot{ }^{43}$ The strikers took over a wage demand the unions had already issued a few months before. The Rotterdam department of the employers' organisation Metaalbond still practised the same policy they had up to and beyond the Second World War. They would not negotiate during the strike and refused to pay for strike-days (a demand often made during strikes). The newcomer Verolme, on his own, hardened the employers' attitude by declaring in the midst of the conflict that, although business was going well, he would decrease the workers' share of the distribution of profits. This incited a general strike at the Verolme yard and radicalised the other shipbuilding workers in the Rotterdam area. Despite his provoking the strike, the first to break the ranks was Verolme, but the other employers followed suit quickly. After all, business was recovering after the decline of the early 1960 s (see Figure 7.1). When Verolme gave in to the demands, the workers of Wilton-Fijenoord took this as their inspiration to walk out. Under the leadership of an action committee, the shipyard was occupied during the Zwarte Nacht van Wilton-Fijenoord (Wilton-Fijenoord night). ${ }^{44}$ Management of Wilton-Fijenoord soon submitted, as did the other companies. At one point, more than 10,000 workers of 13 companies were on strike in the Rotterdam metal industry. They all gained the wage rise they desired.

The 1965 Rotterdam metal strike was decisive for years to come. The unity within the Metaalbond was broken by the strike, and, according to the sociologist J.M.W. Binneveld, who has studied the strike thoroughly, future strikes in shipbuilding were enabled by the 1965 events. ${ }^{45} \mathrm{~A}$ few small strikes occurred between 1965 and the big outburst of worker discontent in 1970. In one simultaneous but disconnected movement the dockers and metalworkers of the Rotterdam area came out without union support at the end of August 1970. On the docks almost 20,000 workers in Rotterdam and Amsterdam struck for more than 2 weeks from 28 August. The metalworkers preceded the dockers by three days when the workers of Wilton-Fijenoord walked out.

Both employers and the leaderships of labour unions showed that they had been slow to understand the rationale of strikes since 1965. The August 1970 strike took them by surprise and, despite several attempts at negotiation, the strike continued. One of the union executives declared in a national newspaper: "We don't support the strike because we feel tied

43 This strike is described and analyzed in Binneveld, De stakingen in de Rotterdamse metaalindustrie in 1965 .

44 Henriks et al., De zwarte nacht van Wilton-Fijenoord.

45 Binneveld, De stakingen in de Rotterdamse metaalindustrie in $1965,62$. 
to the collective agreement. ${ }^{m 6}$ On a national level there were also negotiations within the extant tripartite system. Because almost everyone in these institutions felt that there was a growing discontent among Dutch workers, they agreed that all workers should receive a one-off extra payment of 400 guilders in 1970. This agreement caused the metalworkers to resume work, while the dockers continued the strike for a further week.

The discussion within the union movement about the lack of connection between leadership and the members, which had begun around 1960 , revived. The leadership realised that the voice of the members had to be heard if the union executives wanted to prevent being taken by surprise in the future. Over the next few years, a higher proportion of strikes than during the preceding decades occurred, and now most strikes were initiated and led by the unions. It seemed the waves of wildcat strikes that had swept the Netherlands during the 1950s and 196os had come to an end.

However, in 1972 there was a very large wildcat strike in shipbuilding. On 4 February the workers of RDM began the strike, and they were followed by many colleagues at short notice. One day later, 30,000 workers in Amsterdam and Rotterdam were on strike in protest against a court order that forbade the metal unions to issue a strike call. The fact that the lawyer for the employers stated in court that the workers' meetings summoned by the unions reminded him of the meetings of the Nazi party in Nuremberg ${ }^{47}$ aroused a lot of anger among the workers. This strike also expanded to a shipyard in Zaandam and De Schelde in Vlissingen.

It took twenty-one days before the strikers - who continued their struggle without any financial compensation - realised that they would not receive the rise the unions had asked for. Although this strike was unofficial, it was recognised that union cadres took the lead in many instances. ${ }^{48}$ In 1973, things were different. Because of the threat of an economic crisis, there was no more room for offensive strikes and the unions had seemingly learned their lessons from 1970 and 1972. They realised they should take the lead in the future. The entire union movement then launched a series of nation- and industrywide strikes against the threat that rises in prices would no longer be compensated for by the employers. The unions even demanded that this compensation would be paid in an absolute amount, instead of a percentage

46 "Wij staan echter niet achter de staking want wij achten ons gebonden door de CAO": Nieuwe Rotterdamse Courant, 29 August 1970.

47 Kommunistiese Eenheidsbeweging Nederland (ml), Metaalstaking 1972, 17.

48 Smolders, "Chronologie van de belangrijkste gebeurtenissen voor en tijdens de metaalstaking". 
of wages. Thus wage differences would be levelled, and at the same time the total wage rise would be moderated. ${ }^{49} \mathrm{~A}$ total of more than 80,000 workers (6,00o in shipbuilding) went on strike in this defensive action, totalling more than 600,00o strike-days (110,00o in shipbuilding). During the 1973 Easter weekend, the unions suddenly reached an agreement with the employers. Not all strikers were happy with this, and it took a lot of persuasive power by the union leaders to talk the workers of ADM, NDSM, and Verschure back to work. At the Rotterdam shipyards a reporter noted: "We were mad enough to slave away and now we must back off." ${ }^{\circ}$ After fifty days of a variety of actions, the strike was settled.

The next year that saw a big industrial strike was 1977, again for the maintenance of price-rise compensation. This strike lasted 25 days, and more than 34,000 workers participated under the leadership of the unions. After 270,000 strike-days were lost, the strikers, including the 5,000 shipbuilders, resumed work. The biggest single strike during this action occurred at the Wilton-Fijenoord shipyard where 3,00o workers stopped working for 3 days. During the mid-1970s there was a shift from an offensive to a defensive attitude by labour. As Dutch shipbuilding suffered intense foreign competition and plummeting sales from 1976, its workers lost confidence, and not many joined the last offensive strike movement of that year. Even during later national strikes against a reduction in wages in 1980 and 1982, most shipbuilding workers continued to work. In 1980 only the workers of the independent shipyard Van der Giessen-De Noord struck. However, during the 1982 strike against the diminution of the Sick Leave Act initiated by the social democratic minister of social affairs and employment, more shipbuilding workers followed the strike call by the union movement. They thus protested against the lowering of sick-leave payments by 10 per cent. More than 100,000 workers participated in this strike but they lost, although many employers were forced to compensate their employees for the consequences of the new law in favour of their employees. At almost all the big shipyards the workers joined the strike, despite the difficult situation in shipbuilding. The workers of Wilton-Fijenoord even ignored the fact that a judge forbade them to go on strike. Their wildcat strike was supported by 2,500 workers and ended only after ten days. This was the last big strike in Dutch shipbuilding before the bankruptcy of RSV.

In the meantime a few strikes had occurred in order to prevent this bankruptcy and push the state for more financial support. It began in 1977 during

"We waren gek genoeg om voor sloof te spelen, en nu kunnen we oprotten": ibid., 144. 
a one-day strike by the workers of the Schiedam Gusto shipyard. They went to The Hague to present the government with a petition containing 1,400 signatures asking for more state support for shipbuilding. In 1979 more workers' actions took place urging that the endangered industry be protected. On 4January of that year workers of De Schelde interrupted work for one hour to demand preservation of the yard. In April, strikers at Verolme demanded that the state should negotiate soon about financial support instead of postponing the final decision, and talks were promised. Despite the April strike, state support was not finalised. The union therefore issued a strike call in June, which was backed by 2,700 workers. The strike ended after three days, but other actions continued. In June, the workers of IHC Verschure in Amsterdam received a notification that the restructuring of the company threatened the jobs of 780 of the 3,400 workers. They were not willing to accept this possibility. After a month, the unions advised the workers to stop all kinds of action (on one occasion workers prevented the managing director entering the yard) as management had threatened to stop paying wages. The company decreased the number of workers during the following years. In February 1982 the workers of IHC Verschure occupied the shipyard to prevent a further decrease in the number of employees to just one hundred.

There were more labour actions to stop or redirect the restructuring of the shipbuilding industry but, as we have seen, they were all in vain. The industry has suffered hard times and even as late as 2004 there was a demonstration in The Hague for state support attended by 4,000 workers. Shipbuilding was restructured and the workers had to accept this. Although they had fought the consequences of the restructuring process the number of workers plummeted, as did their strike activity. Meanwhile, what remains of a once-great industry seems to be relatively healthy again, although it is much smaller than before. In 2013, workers in the shipbuilding industry together with their colleagues from the metal industry dared to strike for higher wages again. And they were successful..$^{1}$

\section{Concluding remarks}

Dutch shipbuilding is still vibrant in many niche shipbuilding markets, but it is no longer one of the biggest shipbuilding industries in the world as it was in the 1930s, when it was the third-largest. In 2012 it was the

$5^{1}$ See http://www.fnvbondgenoten.nl/mijnbranche/branches/metalektro/nieuws/ 655996-grootmetaal_werkgevers_komen_211013/. 
fourth-largest - but not on a global scale: only in Europe. Indeed, all European countries together, including Turkey, only made up about 5 per cent of world production..$^{52}$ The big shipyards no longer function as they did: some survive either as repair companies or the yards have been taken over for other purposes..$^{53}$ The Dutch shipbuilding industry has at least retained one of its long-standing specialisms, the building of dredgers. Today, the construction of super-yachts and specialist offshore vessels is prevalent in the Netherlands, which shows that Dutch shipbuilding has found a new niche market to operate in. For example, IHC Holland Merwede is focused on the continuous development of its design and construction activities for the specialised shipbuilding sector, in particular the dredging and offshore industries. IHC Holland Merwede is the world market leader in the construction of specialist dredging equipment and complex custom-built offshore vessels. ${ }^{54}$

After a short period in the 1960 os and 1970s when shipbuilding workers were able to gain higher wages by large and offensive strikes, the tide turned to defensive actions. Shipbuilding as an industry moved to low-wage countries, and the Dutch government's support policy was not able to stop this. The only thing that it accomplished was to delay the advent of high unemployment in Dutch shipbuilding. Ultimately many thousands of workers lost their jobs, and the social environment of many of those workers also crumbled. 
Appendix 7.1 Completed ships in the Netherlands, 1950-1986

\begin{tabular}{|c|c|c|c|c|c|c|}
\hline & \multicolumn{2}{|c|}{ Sea-going } & \multicolumn{2}{|c|}{ Inland vessels } & \multicolumn{2}{|c|}{ Tow-boats and tugboats } \\
\hline & Number & $1,000 \mathrm{GRT}$ & Number & 1,000 tons & Number & $1,000 \mathrm{~kW}$ \\
\hline 1950 & 87 & 195 & 47 & 22 & 35 & 12 \\
\hline 1951 & 115 & 256 & 65 & 29 & 28 & 11 \\
\hline 1952 & 132 & 235 & 38 & 11 & 51 & 9 \\
\hline 1953 & 116 & 287 & 19 & 5 & 52 & 13 \\
\hline 1954 & 119 & 342 & 50 & 18 & 64 & 14 \\
\hline 1955 & 124 & 396 & 70 & 24 & 51 & 11 \\
\hline 1956 & 136 & 399 & 96 & 44 & 56 & 14 \\
\hline 1957 & 172 & 537 & 84 & 38 & 59 & 19 \\
\hline 1958 & 146 & 500 & 91 & 55 & 36 & 13 \\
\hline 1959 & 106 & 564 & 95 & 67 & 32 & 13 \\
\hline 1960 & 116 & 599 & 112 & 56 & 45 & 27 \\
\hline 1961 & 115 & 466 & 144 & 122 & 31 & 13 \\
\hline 1962 & 111 & 544 & 165 & 147 & 66 & 20 \\
\hline 1963 & 77 & 423 & 173 & 137 & 40 & 28 \\
\hline 1964 & 62 & 226 & 188 & 155 & 57 & 22 \\
\hline 1965 & 86 & 111 & 115 & 70 & 58 & 17 \\
\hline 1966 & 90 & 292 & 99 & 76 & 57 & 23 \\
\hline 1967 & 88 & 263 & 54 & 36 & 46 & 9 \\
\hline 1968 & 62 & 228 & 45 & 68 & 62 & 26 \\
\hline 1969 & 76 & 452 & 56 & 56 & 49 & 23 \\
\hline 1970 & 74 & 603 & 83 & 88 & 70 & 29 \\
\hline 1971 & 79 & 565 & 83 & 124 & 85 & 45 \\
\hline 1972 & 79 & 750 & 94 & 143 & 92 & 37 \\
\hline 1973 & 60 & 792 & 78 & 127 & 88 & 41 \\
\hline 1974 & 64 & 895 & 53 & 75 & 113 & 52 \\
\hline 1975 & 86 & 991 & 50 & 59 & 96 & 76 \\
\hline 1976 & 82 & 594 & 25 & 21 & 110 & 96 \\
\hline 1977 & 70 & 204 & 15 & 11 & 65 & 55 \\
\hline 1978 & 53 & 320 & 20 & 12 & 55 & 64 \\
\hline 1979 & 52 & 172 & 53 & 71 & 29 & 16 \\
\hline 1980 & 22 & 92 & 88 & 137 & 71 & 62 \\
\hline 1981 & 25 & 102 & 69 & 106 & 80 & 66 \\
\hline 1982 & 46 & 162 & 44 & 81 & 85 & 95 \\
\hline 1983 & 38 & 139 & 9 & 8 & 69 & 90 \\
\hline 1984 & 30 & 109 & 30 & 52 & 28 & 30 \\
\hline 1985 & 45 & 109 & 29 & 36 & 33 & 36 \\
\hline 1986 & 28 & 95 & 25 & 48 & 24 & 24 \\
\hline
\end{tabular}

Note: 1950-62 companies $\geq 25$ employees, 1963-86 all companies $\geq 10$ employees

Source: CBS, Produktiestatistieken Industrie. Scheepsbouw- en scheepsbouwreparatiebedrijven 1986,37 
Appendix 7.2 Number of companies and number of employees in shipbuilding and ship repair, 1951-1986

\begin{tabular}{|c|c|c|}
\hline & Number of companies & Number of employees \\
\hline 1951 & 136 & 48,338 \\
\hline 1952 & 134 & 50,882 \\
\hline 1953 & 139 & 51,795 \\
\hline 1954 & 150 & 52,746 \\
\hline 1955 & 156 & 53,191 \\
\hline 1956 & 163 & 54,202 \\
\hline 1957 & 175 & 56,054 \\
\hline 1958 & 173 & 56,074 \\
\hline 1959 & 170 & 54,011 \\
\hline 1960 & 171 & 52,623 \\
\hline 1961 & 172 & 51,866 \\
\hline 1962 & 243 & 53,006 \\
\hline 1963 & 254 & 50,490 \\
\hline 1964 & 250 & 48,653 \\
\hline 1965 & 250 & 47,704 \\
\hline 1966 & 256 & 46,600 \\
\hline 1967 & 245 & 46,595 \\
\hline 1968 & 246 & 46,074 \\
\hline 1969 & 253 & 45,827 \\
\hline 1970 & 252 & 45,685 \\
\hline 1971 & 249 & 48,191 \\
\hline 1972 & 253 & 49,258 \\
\hline 1973 & 258 & 48,080 \\
\hline 1974 & 255 & 47,452 \\
\hline 1975 & 257 & 47,577 \\
\hline 1976 & 257 & 45,410 \\
\hline 1977 & 246 & 42,106 \\
\hline 1978 & 238 & 38,104 \\
\hline 1979 & 238 & 34,443 \\
\hline 1980 & 230 & 32,466 \\
\hline 1981 & 264 & 34,526 \\
\hline 1982 & 250 & 34,538 \\
\hline 1983 & 247 & 29,612 \\
\hline 1984 & 223 & 27,081 \\
\hline 1985 & 222 & 24,525 \\
\hline 1986 & 213 & 22,698 \\
\hline
\end{tabular}

Note: all companies $\geq 10$ employees

Source: CBS, Produktiestatistieken Industrie. Scheepsbouw- en scheepsbouwreparatiebedrijven 1986,37 
Appendix 7.3 Strikes in the Dutch shipbuilding industry, 1950-2013

\begin{tabular}{|c|c|c|c|}
\hline & Total number of strikers & Strike-days & Number of strikes \\
\hline 1950 & 1,009 & 17,933 & 5 \\
\hline 1951 & 5,745 & 6,470 & 5 \\
\hline 1952 & 230 & 29 & 1 \\
\hline 1953 & 6,396 & 5,125 & 4 \\
\hline 1954 & 2,201 & 12,253 & 8 \\
\hline 1955 & 2,568 & 17,409 & 9 \\
\hline 1956 & 5,502 & 2,629 & 6 \\
\hline 1957 & 367 & 1,613 & 5 \\
\hline 1958 & 286 & 429 & 1 \\
\hline 1959 & 380 & 333 & 1 \\
\hline 1960 & 17,866 & 14,468 & 9 \\
\hline 1961 & 410 & 878 & 2 \\
\hline 1962 & 120 & 800 & 2 \\
\hline 1963 & 400 & 795 & 3 \\
\hline 1964 & 1,929 & 2,003 & 3 \\
\hline 1965 & 15,195 & 30,285 & 3 \\
\hline 1966 & 458 & 816 & 2 \\
\hline 1967 & 1,111 & 1,022 & 2 \\
\hline 1968 & 2,000 & 6,000 & 1 \\
\hline 1969 & 1,620 & 1,214 & 4 \\
\hline 1970 & 30,470 & 128,510 & 5 \\
\hline 1971 & 1,672 & 1,215 & 4 \\
\hline 1972 & 30,820 & 400,153 & 4 \\
\hline 1973 & 6,246 & 110,411 & 1 \\
\hline 1974 & 1,000 & 288 & 2 \\
\hline 1975 & . & . & 1 \\
\hline 1976 & 435 & 83 & 4 \\
\hline 1977 & 6,100 & 17,725 & 6 \\
\hline 1978 & 1,000 & 125 & 4 \\
\hline 1979 & 7,880 & 9,472 & 9 \\
\hline 1980 & 1,800 & 21,071 & 2 \\
\hline 1981 & 4,243 & 698 & 6 \\
\hline 1982 & 8,678 & 19,250 & 3 \\
\hline 1983 & 2,060 & 260 & 3 \\
\hline 1984 & 2,500 & . & 1 \\
\hline 1985 & 1,770 & . & 3 \\
\hline 1986 & 97 & 30 & 1 \\
\hline 1987 & . & . & 0 \\
\hline 1988 & . & . & 0 \\
\hline 1989 & 90 & 0 & 1 \\
\hline 1990 & . & . & 1 \\
\hline 1991 & . & . & 1 \\
\hline
\end{tabular}




\begin{tabular}{|c|c|c|c|}
\hline & Total number of strikers & Strike-days & Number of strikes \\
\hline 1992 & 300 & 37 & 1 \\
\hline 1993 & 500 & 312 & 1 \\
\hline 1994 & 300 & 300 & 1 \\
\hline 1995 & & . & 0 \\
\hline 1996 & . & . & 1 \\
\hline 1997 & . & . & 0 \\
\hline 1998 & . & . & 0 \\
\hline 1999 & . & 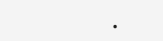 & 0 \\
\hline 2000 & . & . & 0 \\
\hline 2001 & . & . & 0 \\
\hline 2002 & . & . & 0 \\
\hline 2003 & 70 & 18 & 1 \\
\hline 2004 & . & . & 1 \\
\hline 2005 & . & . & 0 \\
\hline 2006 & . & . & 0 \\
\hline 2007 & . & . & 0 \\
\hline 2008 & . & . & 0 \\
\hline 2009 & . & . & 0 \\
\hline 2010 & . & . & 0 \\
\hline 2011 & . & . & 0 \\
\hline 2012 & . & . & 0 \\
\hline 2013 & . & . & 1 \\
\hline
\end{tabular}




\section{Appendix 7.4 History of RSV}

History of RSV

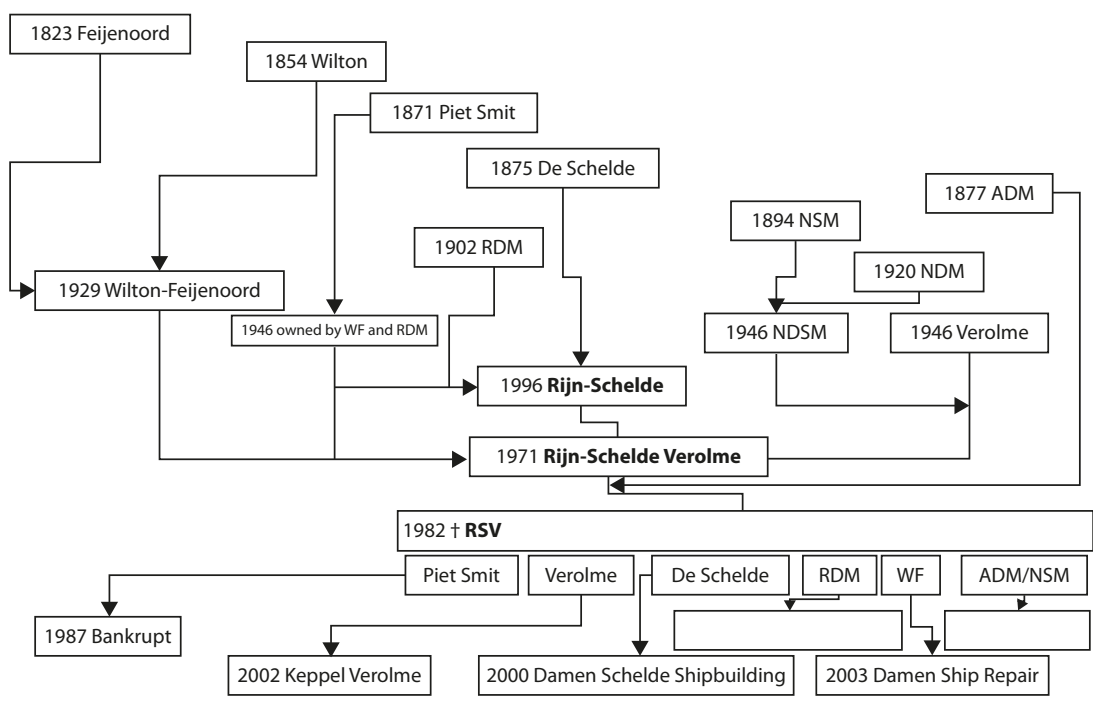


A Amsterdam

U University

P Press 